
Д. А. Кассим /к. т. н./, А. К. Тараканов /д. т. н./, В. П. Лялюк /Д. т. н./
П. И. Оторвин /к. т. н./, А. А. Гусев

Национальная металлургическая академия Украины, г. Днипро, Украина ПАО «АрселорМиттал Кривой Рог», г. Кривой Рог, Украина

\title{
Влияние качества агломерата и кокса на технико-экономические показатели доменной плавки
}

D. A. Kassim /Cand. Sci. (Tech.)/, A. K. Tarakanov /Dr. Sci. (Tech.)/, V. P. Lyalyuk /Dr. Sci. (Tech.)/

P. I. Otorvin /Cand. Sci. (Tech.)/, A. A. Gusev
National Metallurgical Academy of Ukraine, Dnipro, Ukraine

“ArcelorMittal Kryviy Rih”, Kryviy Rih, Ukraine

\section{Influence of quality of agglomerate and coke on technical and economic indices of blast furnace smelting}

Цель. Сравнить результаты эффективности доменной плавки при изменении качественных характеристик агломерата и кокса, а также расчетных показателей дутьевого режима плавки.

Методика. Анализ технико-экономических показателей работы доменных печей в периоды работы на агломерате с разными металлургическими характеристиками и разным диаметром фурм.

Результаты. Опыт работы доменных печей объемом 2700 и 2000 м³ подтвердил известный фракт зависимости производительности печей и расхода кокса не только от качества шихтовых материалов, но и от распределения газового потока по сечению печи.

Научная новизна. Выполнен технологический анализ результатов работы доменных печей объемом 2700 и 2000 м $^{3}$ при изменении качества агломерата и кокса в сочетании с изменением параметров дутьевого режима плавки. На основании выполненного анализа подтверждена целесообразность повышения газопроницаемости шихты за счет улучшения качества сырья при одновременном увеличении полных механических энергий комбинированного дутья и горнового газа, отвечающих за длину зоны горения и глубину проникновения газового потока к центру горна доменной печи.

Практическая значимость. Чередование фурм разного диаметра, наряду с улучшением качественных характеристик шихтовых материалов, дополнительно способствует усилению положительного эфффекта за счет расширения зон горения в горне печи. А если при этом растет полная механическая энергия горнового газа и увеличивается глубина проникновения горнового газа к оси печи, эффрект от использования высококачественного сырья может быть максимальным. (Ил. 3. Табл. 3. Библиогр.: 7 назв.)

Ключевые слова: агломерат, кокс, дутье, фурмы, газопроницаемость, качество, полная энергия.

Фактический материал. В феврале 2018 г. доменная печь № 9 объемом $5000 \mathrm{~m}^{3}$ ПАО «АрселорМиттал Кривой Рог» (АМКР) была остановлена на капитальный ремонт. Как обычно в этом случае, высококачественный агломерат агломерационного цеха (АЦ) № 2 аглодоменного департамента (АДД) АМКР был подан в бункера шихтоподачи доменной печи № 8 объемом 2700 м $^{3}$ (табл. 1), а также в отдельные периоды поступал и на печь № 6 объемом $2000 \mathrm{~m}^{3}$ (табл. 2).

В этот период работы на доменную печь № 8 поступал кокс с высокими значениями показателя послереакционной прочности CSR. Показатель CSR был на уровне 53,6-54,7 \%. Из табл. 1 видно, что при переводе доменной печи на агломерат с пониженным содержанием мелочи (0-5 мм) производительность доменной печи № 8 выросла с 4672 до 5426 т/сут. (на 13,9 \%) при снижении расхода кокса на 19,2 кг/т чуг., или на 4,2 \%. При этом расход дутья на печи удалось увеличить на $287 \mathrm{~m}^{3} /$ мин. Интенсивность плавки по сожжённому коксу выросла с 862 до 922 т/ (м³.сут.). Температура колошникового газа снизилась с 296 до $223^{\circ} \mathrm{C}$. Степень использования газа увеличилась с 41 до 46 \%, главным образом из-за снижения удельного расхода кокса.

Аналогичные результаты были получены и на доменной печи № 6 (табл. 2). Обычно эта печь работает на агломерате АЦ МП (аглоцех металлургического производства АДД АМКР), на который поступают все отсевы, шламы, пыли и другие отходы. Содержание мелочи 0-5 мм в агломерате АЦ МП всегда больше 20-25 \% . Загрузка в доменную печь № 6 агломерата АЦ-1 и 
Таблица 1

Технико-экономические показатели работы доменной печи объемом $2700 \mathrm{M}^{3}$

\begin{tabular}{|c|c|c|}
\hline \multirow{2}{*}{ Показатели } & \multicolumn{2}{|c|}{ Период } \\
\hline & Б & $\mathrm{O}$ \\
\hline Длительность периода, сут. & 31 & 8 \\
\hline Производительность, т/сут. & 4672 & 5426 \\
\hline Приведенная производительность, т/сут. & 4672 & 4886 \\
\hline Расход кокса $(\mathrm{K})$, кг/т & 471,2 & 452,0 \\
\hline Приведенный расход кокса, кг/т & 471,2 & 460,0 \\
\hline Расход антрацита (А), кг/т & 26,9 & 7,0 \\
\hline 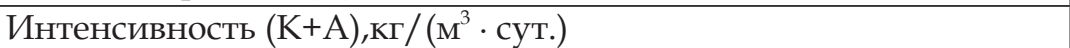 & 862 & 922 \\
\hline $\begin{array}{l}\text { Дутье: расход, м³ /мин } \\
\text { давление (изб.), кПа } \\
\text { температура, }{ }^{\circ} \mathrm{C}\end{array}$ & $\begin{array}{l}4221 \\
261 \\
996\end{array}$ & $\begin{array}{c}4508 \\
271 \\
1041 \\
\end{array}$ \\
\hline Расход природного газа, м $^{3} / \mathrm{T}$ & 49,6 & 66,0 \\
\hline Содержание кислорода в дутье, \% & 24,2 & 26,0 \\
\hline $\begin{array}{r}\text { Колошниковый газ: температура, }{ }^{\circ} \mathrm{C} \\
\text { давление, кПа (изб.) } \\
\text { содержание \%: } \mathrm{CO} \\
\mathrm{CO}_{2} \\
\mathrm{H}_{2} \\
\eta_{\mathrm{co}}\end{array}$ & $\begin{array}{l}296 \\
126 \\
24,7 \\
17,5 \\
3,3 \\
0,41\end{array}$ & $\begin{array}{c}223 \\
139 \\
25,0 \\
21,0 \\
4,2 \\
0,46\end{array}$ \\
\hline $\begin{array}{r}\text { Анализ чугуна, \%: } \mathrm{Si} \\
\mathrm{Mn} \\
\mathrm{S} \\
\mathrm{P}\end{array}$ & $\begin{array}{l}0,75 \\
0,15 \\
0,016 \\
0,090\end{array}$ & $\begin{array}{l}0,72 \\
0,14 \\
0,025 \\
0,108\end{array}$ \\
\hline Текущие простои/тихий ход, \% & $2,77 / 0,04$ & $0 / 0$ \\
\hline Содержание Fе в рудной части шихты, \% & 55,43 & 56,00 \\
\hline $\begin{aligned} \text { Расходы, кг/т: железная руда } \\
\text { агломерат АЦ МП } \\
\text { агломерат АЦ №1 } \\
\text { агломерат АЦ №2 } \\
\text { скрап } \\
\text { известняк }\end{aligned}$ & $\begin{array}{c}9,4 \\
95 \\
1613 \\
645 \\
42 \\
5,4 \\
\end{array}$ & $\begin{array}{c}4,0 \\
0 \\
341 \\
1238 \\
38 \\
9,0\end{array}$ \\
\hline Основность шлака, ед. & 1,21 & 1,25 \\
\hline $\begin{array}{r}\text { Качество кокса, \%: сера } \\
\text { зола } \\
\mathrm{M}_{25} \\
\mathrm{M}_{10} \\
\text { CSR } \\
\text { CRI }\end{array}$ & $\begin{array}{c}0,50 \\
11,2 \\
86,1 \\
7,4 \\
53,6 \\
36,7\end{array}$ & $\begin{array}{c}0,40 \\
11,2 \\
84,9 \\
7,5 \\
54,7 \\
36,6\end{array}$ \\
\hline $\begin{array}{r}\text { Фракция 0-5 мм, \%: агломерат АЦ МП } \\
\text { агломерат АЦ №1 } \\
\text { агломерат АЦ №2 } \\
\text { Средневзвешенная фракция 0-5 мм, \% }\end{array}$ & $\begin{array}{c}20,25 \\
14,14 \\
8,72 \\
14,26\end{array}$ & $\begin{array}{c}- \\
14,19 \\
6,53 \\
8,18\end{array}$ \\
\hline Кинетическая энергия комбинированного дутья, кДж/с & 148,3 & 178,9 \\
\hline Энергия давления комбинированного дутья, кДж/с & 1621,7 & 1761,2 \\
\hline Полная механическая энергия комбинированного дутья, кДж/с & 1770,0 & 1940,1 \\
\hline Выход горнового газа, $\mathrm{m}^{3} / \mathrm{c}$ & 93,4 & 103,7 \\
\hline Теоретическая температура горения, ${ }^{\circ} \mathrm{C}$ & 2109,4 & 2133,0 \\
\hline Энергия давления горнового газа, кДж/с & 3176,6 & 3560,6 \\
\hline Полная механическая энергия горнового газа, кДж/с & 3325,9 & 3739,5 \\
\hline
\end{tabular}




\section{Технико-экономические показатели работы доменной печи объемом 2000 м $^{3}$}

\begin{tabular}{|c|c|c|}
\hline \multirow[b]{2}{*}{ Показатели } & \multicolumn{2}{|c|}{ Период } \\
\hline & Б & $\mathrm{O}$ \\
\hline Длительность периода, сут. & 31 & 15 \\
\hline Производительность, т/сут. & 3157 & 3879 \\
\hline Приведенная производительность, т/сут. & 3157 & 3441 \\
\hline Расход кокса $(\mathrm{K})$, кг/т & 497,0 & 447,1 \\
\hline Приведенный расход кокса, кг/т & 497,0 & 466,0 \\
\hline Расход антрацита (А), кг/т & 13,6 & 4,6 \\
\hline 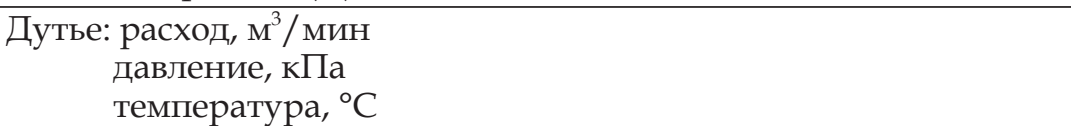 & $\begin{array}{c}2948 \\
224 \\
1020\end{array}$ & $\begin{array}{l}3192 \\
248 \\
1047\end{array}$ \\
\hline Интенсивность (К+А),кг/(м ${ }^{3} \cdot$ сут.) & 806 & 876 \\
\hline Расход природного газа, $\mathrm{M}^{3} / \mathrm{T}$ & 51,1 & 77,3 \\
\hline Содержание кислорода в дутье, \% & 23,8 & 26,8 \\
\hline $\begin{array}{r}\text { Колошниковый газ: температура, }{ }^{\circ} \mathrm{C} \\
\text { давление, кПа (изб.) } \\
\text { содержание \%: } \mathrm{CO} \\
\mathrm{CO}_{2} \\
\mathrm{H}_{2} \\
\eta_{\mathrm{co}} \\
\end{array}$ & $\begin{array}{c}305 \\
102 \\
24,01 \\
17,8 \\
3,01 \\
0,43 \\
\end{array}$ & $\begin{array}{c}248 \\
120 \\
20,5 \\
17,8 \\
4,1 \\
0,46\end{array}$ \\
\hline $\begin{array}{r}\text { Анализ чугуна, \%: } \mathrm{Si} \\
\mathrm{Mn} \\
\mathrm{S} \\
\mathrm{P}\end{array}$ & $\begin{array}{c}0,77 \\
0,19 \\
0,017 \\
0,090\end{array}$ & $\begin{array}{c}0,80 \\
0,18 \\
0,023 \\
0,107\end{array}$ \\
\hline Текущие простои/тихий ход, \% & $2,58 / 0,35$ & $0,2 / 0$ \\
\hline Содержание Fе в рудной части шихты, \% & 55,43 & 55,90 \\
\hline $\begin{array}{l}\text { Расходы, кг/т: железная руда } \\
\text { агломерат АЦ МП } \\
\text { агломерат АЦ №1 } \\
\text { агломерат АЦ №2 } \\
\text { скрап } \\
\text { известняк }\end{array}$ & $\begin{array}{c}6,0 \\
1191,4 \\
557,1 \\
41,5 \\
27,9 \\
5,3\end{array}$ & $\begin{array}{c}9,5 \\
619,9 \\
784,1 \\
245,8 \\
38,2 \\
1,6\end{array}$ \\
\hline Основность шлака, ед. & 1,19 & 1,27 \\
\hline $\begin{array}{r}\text { Качество кокса, \%: сера } \\
\text { зола } \\
\mathrm{M}_{25} \\
\mathrm{M}_{10} \\
\text { CSR } \\
\text { CRI }\end{array}$ & $\begin{array}{c}0,5 \\
11,2 \\
86,1 \\
7,4 \\
53,6 \\
36,7\end{array}$ & $\begin{array}{l}0,4 \\
11,2 \\
85,2 \\
7,5 \\
54,3 \\
36,3\end{array}$ \\
\hline $\begin{array}{r}\text { Фракция 0-5 мм, \%: агломерат АЦ МП } \\
\text { агломерат АЦ №1 } \\
\text { агломерат АЦ №2 } \\
\text { Средневзвешенная фракция 0-5 мм, \% }\end{array}$ & $\begin{array}{c}20,25 \\
14,14 \\
8,72 \\
18,08\end{array}$ & $\begin{array}{c}20,25 \\
14,19 \\
6,53 \\
15,32\end{array}$ \\
\hline Кинетическая энергия комбинированного дутья, кДж/с & 106,5 & 119,5 \\
\hline Энергия давления комбинированного дутья, кДж/с & 1358,3 & 1471,1 \\
\hline Полная механическая энергия комбинированного дутья, кДж/с & 1464,8 & 1590,6 \\
\hline Выход горнового газа, $\mathrm{m}^{3} / \mathrm{c}$ & 65,1 & 74,9 \\
\hline Теоретическая температура горения, ${ }^{\circ} \mathrm{C}$ & 2107,5 & 2120,6 \\
\hline Энергия давления горнового газа, кДж/с & 2611,5 & 3024,6 \\
\hline Полная механическая энергия горнового газа, кДж/с & 2718 & 3144,1 \\
\hline
\end{tabular}


АЦ-2 привела к росту производительности доменной печи на 722 т/ сут. (18,6 \%) и снижению расхода кокса на 49,9 кг/т. Расход дутья удалось поднять на $244 \mathrm{~m}^{3}$ / мин. Здесь также повысились степень использования тепловой (температура колошникового газа снизилась с 305 до $\left.248^{\circ} \mathrm{C}\right)$ и восстановительной энергии газового потока ( выросла с 43 до 46 \%).

На доменных печах № 8 и 6 после установки на них засыпных аппаратов с лепестковым распределителем шихты (ЛРШ) [1] и последующей заменой ЛРШ на калибратор Тарасова [2] (оба распределителя выгружают шихтовые материалы через узкое кольцо, наподобие песочных часов) используется раздельная система загрузки (AАAA $\downarrow$ KККК $\downarrow$ ) вместо циклической совместной системы. При этом масса подачи на печи объемом 2000 м изменяется в пределах 60-85 т, а на печи 2700 м³ - 80-104 т. Уровень засыпи составлял 1,5-1,75 м. На доменной печи № 8 в базовом и опытном периодах (табл. 1) из 28 воздушных фурм диаметром 140 мм работали 26, а на доменной печи № 6 (табл. 2) из 24 фурм диаметром 140 мм работали 22 фурмы.

Изменения кинетических энергий комбинированного дутья, энергий давления и полных механических энергий комбинированного дутья, а также энергий давления и полных механических энергий горнового газа в базовых и опытных периодах приведены в табл. 1 и 2.

Рассчитать полные механические энергии комбинированного дутья $\left(\mathrm{E}_{\text {пм кд }}\right)$ и горнового газа $\left(\mathrm{E}_{\text {пм гг }}\right)$ можно по формулам [3; 4]:

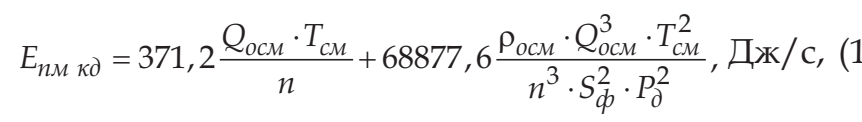

где $Q_{\text {осм }}$ - приведенный к нормальным условиям расход газо-воздушной смеси, образующейся в связи с частичным горением природного газа в полости фурмы, $\mathrm{Hм}^{3} /$ с;

$T_{c м}$ - температура этой смеси, K;

$\rho_{\text {осм }}$ - плотность смеси при нормальных условиях, Кг $/ \mathrm{M}^{3}$;

$n$ - количество работающих воздушных фурм;

$S_{\phi}$ - площадь сечения фурмы, $\mathrm{M}^{2}$;

$P_{\partial}$ - абсолютное давление дутья, Па.

$$
E_{n \mathcal{M} \kappa \partial}=371,2 \frac{Q_{o c M} \cdot T_{\mathcal{C M}}}{n}+68877,6 \frac{\rho_{o c M} \cdot Q_{o c M}^{3} \cdot T_{c M}^{2}}{n^{3} \cdot S_{\phi}^{2} \cdot P_{\partial}^{2}}, \text { Дж/c, (2) }
$$

где $Q_{\text {оге }}$ - выход горновых газов, приведенный к нормальным условиям, $\mathrm{m}^{3} / \mathrm{c}$;

$T_{m}$ - температура в зоне горения (теоретическая температура горения), К.

Радиальный газ на этих печах в исследуемых периодах из-за ремонта машин отбора проб газа не осуществлялся, но на колошниках печей уста- новлены термобалки для контроля распределения газового потока над уровнем засыпи.

На рис. 1 и 2 приведены диаграммы изменения температуры газа на колошниках печей № 8 и 6, измеренных в восьми точках двумя термозондами, расположенными противоположно по диаметру колошника каждой печи. Из рис. 1 видно, что доменная печь № 8 работала с явно выраженным осевым потоком газа в базовом и опытном периодах, однако в опытном периоде произошло снижение температуры газового потока на периферии (точки 1 и 1) и его усиление в осевой зоне печи (точки 8-8), что объясняется увеличением полных механических энергий комбинированного дутья и горнового газа, отвечающих за длину зоны горения и глубину проникновения газового потока к центру горна доменной печи [3; 4]. Аналогичное перераспределение температур произошло и на доменной печи № 6 (рис. 2), что также связано с перераспределением газового потока в горне печи.

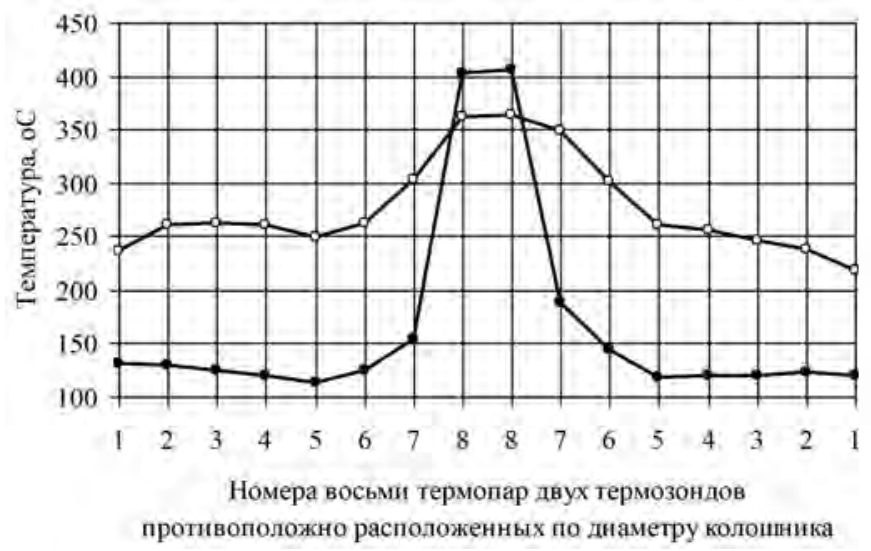

Рис. 1. Диаграммы изменения температур термозондами на колошнике доменной печи № 8: -о- базовый период (Б);

-•- опытный период (О); табл. 1

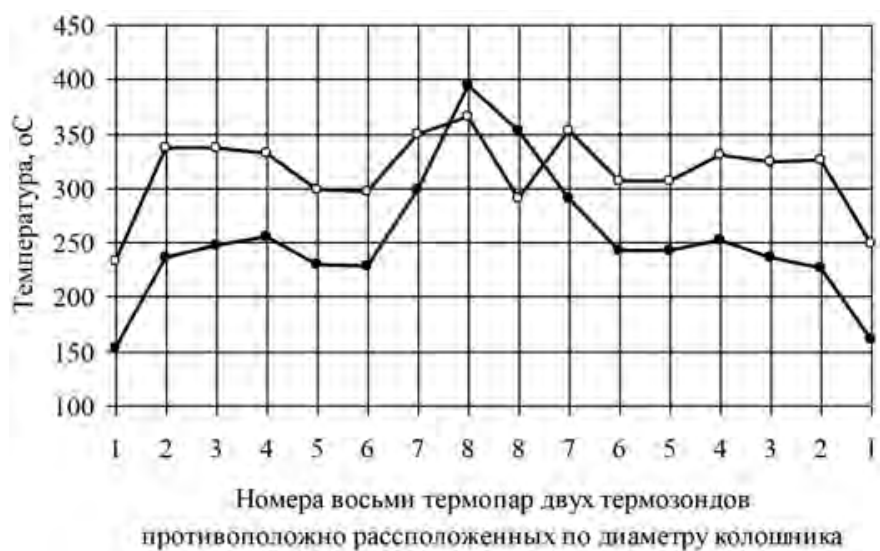

Рис. 2. Диаграммы изменения температур термозондами на колошнике доменной печи № 6: -о- базовый период (Б);

- •- опытный период (О); табл. 2 
Из табл. 1 и 2 видно, что при переводе работы доменных печей на агломерат АЦ-2 все энергетические характеристики дутья и горнового газа заметно выросли. Поэтому представляется целесообразным изучение опыта работы доменной печи № 8 при одновременном улучшении качества агломерата и повышении энергетических параметров газо-дутьевого режима плавки. Для этого необходимо обратиться к первому опыту загрузки высококачественного агломерата аглофабрики НКГОК-2 (в настоящее время АЦ-2 АДД АМКР) в эту доменную печь $[5 ; 6]$.

Впервые агломерат ЮГОКа (табл. 3 Б - базовый период) на печи № 8 заменили на грохоченный, освобожденный от мелочи, охлажденный, высокоосновный агломерат (основностью 1,57) НКГОК-2 в феврале 1977 г. (табл. 3, О 2 - второй опытный период). В этот период производительность доменной печи относительно базового периода увеличилась до 6012 т/сут. - на 26,3% [5; 6].

Однако, как показали последующие периоды работы доменной печи № 8 на этом агломерате [7], относить весь положительный эффект, полученный в первый период использования агломерата НКГОК-2, только на счет высокого качества агломерата неверно, т. к. больше ни разу не была получена такая высокая производительность печи.

Первоначальной загрузке в печь № 8 агломерата НКГОК-2 предшествовала установка на печи фурм диаметром 207 мм через одну при чередовании с фурмами диаметром 190 мм (табл. 3, О - первый опытный период) [6]. В январе 1977 г. (базовый период Б) печь работала на 23 фурмах (при одной закрытой) диаметром 190 мм, а 31 января вместо чётных фурм диаметром 190 мм установили 11 фурм диаметром 207 мм. В таком режиме печь проработала 18 суток, и затем на печь поступил агломерат НКГОК-2.

Как видно из табл. 3, при переводе работы доменной печи № 8 с фурм диаметром 190 мм на чередование фурм 190/207 мм производительность печи увеличилась с 4759 до 5108 т/сут., т. е. на 7,3 \%. Последующая замена агломерата ЮГОК на агломерат НКГОК-2 при уменьшении содержания фракции 0-5 мм в шихте с 16,5 до 8,8 \% привела к дальнейшему росту производительности печи до 6012 т/сут. (удельная производительность - 2,23 т/ м $^{3} \cdot$ сут).

В периоды Б, $\mathrm{O}_{1}$ и $\mathrm{O}_{2}$ (табл. 3) циклическая система загрузки и уровень засыпи на печи не изменялись, в периоде $\mathrm{O}_{2}$ незначительно увеличили массу подачи с 40 до 43 т [6]. Из табл. 3 также видно, что оба эти мероприятия позволили интенсифицировать доменную плавку дутьем на $200 \mathrm{~m}^{3}$ /мин. При этом интенсивность плавки по сожженному коксу последовательно росла с 918 до 969 и затем до 1055 т/ (м³.сут.). Удельный расход кокса при переходе от одного мероприятия к другому последовательно снижался с 521 до 512 и затем до 474 кг/т, т. е. суммарно на 47 кг/ т чугуна.

Изменение содержания $\mathrm{CO}_{2}$ в газе по радиусу колошника печи в эти периоды (рис. 3) показало, что при переводе работы печи с фурм диаметром 190 мм на чередование фурм диаметром 190/207 мм при использовании агломерата ЮГОК произошло перераспределение газового потока, характеризовавшееся увеличением количества газа, проходящего по периферийной и осевой зонам печи, что соответствует незначительному одновременному раскрытию периферии и центра. А при подаче на печь агломерата НКГОК-2 произошла подгрузка периферии и значительное раскрытие центра печи. Объясняется это повышением газопроницаемости шихты, а также увеличением полных механических энергий комбинированного дутья и горнового газа, отвечающих соответственно за длину зоны горения и за глубину проникновения газового потока к центру горна доменной печи.

Кинетическая энергия комбинированного дутья на срезе фурмы в базовом периоде (табл. 3) составила 53,5 кДж/с. Рассчитать точно кинетические энергии комбинированного дутья в опытных периодах $\mathrm{O}_{1}$ и $\mathrm{O}_{2}$ не представляется возможным из-за отсутствия данных по расходу дутья на фурмах диаметром 190 и 207 мм при их чередовании. Однако если взять средний диаметр фурм (198 мм), то условно можно рассчитать

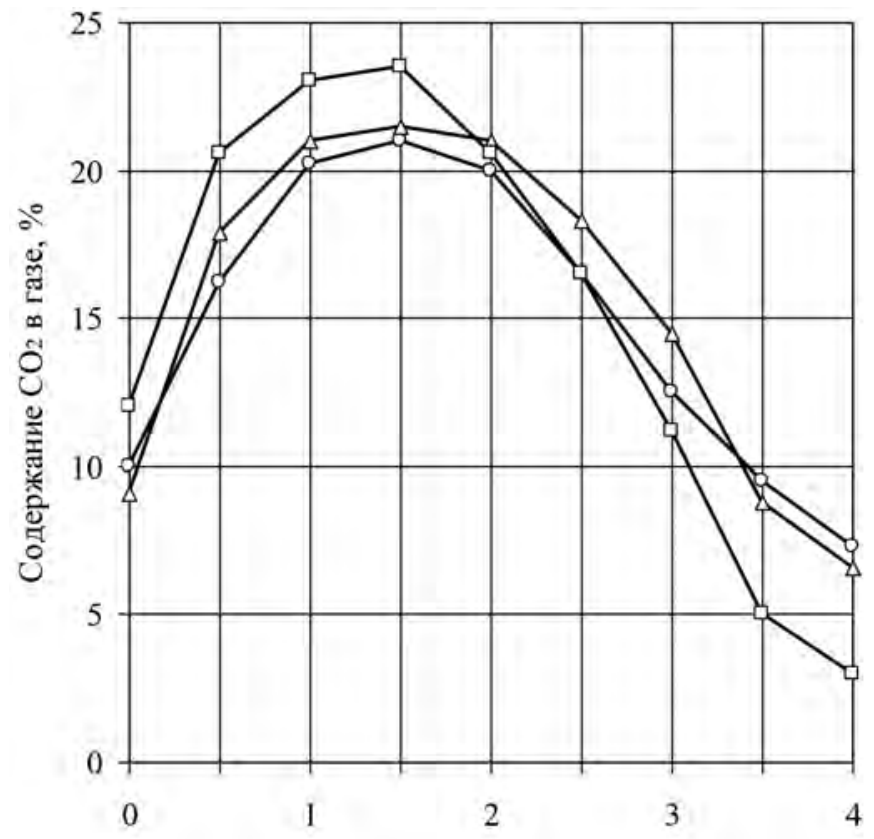

Расстояние от стенки колошника, м

Рис. 3. Изменение содержания $\mathrm{CO}_{2}$ в газе по радиусу колошника доменной печи объемом $2700 \mathbf{m}^{3}$

(периоды табл. 1: -о- Б, $-\Delta-\mathrm{O}_{1},-\square-\mathrm{O}_{2}$ ) 
Таблица 3

Технико-экономические показатели работы доменной печи объемом 2700 м $^{3}$

\begin{tabular}{|c|c|c|c|}
\hline \multirow{2}{*}{ Показатели } & \multicolumn{3}{|c|}{ Период } \\
\hline & Б & O1 & $\mathrm{O} 2$ \\
\hline Длительность периода, сут. & 30 & 18 & 6 \\
\hline Производительность, т/сут. & 4759 & 5108 & 6012 \\
\hline Расход кокса, кг/т & 521 & 512 & 474 \\
\hline Интенсивность, кг /( М $^{3}$ с сут. $)$ & 918 & 969 & 1055 \\
\hline $\begin{array}{c}\text { Дутье: расход, м³ /мин } \\
\text { давление, кПа (изб.) } \\
\text { температура, }{ }^{\circ} \mathrm{C}\end{array}$ & $\begin{array}{l}4733 \\
333 \\
899\end{array}$ & $\begin{array}{l}4933 \\
331 \\
874\end{array}$ & $\begin{array}{c}4915 \\
335 \\
1095\end{array}$ \\
\hline Расход природного газа, $\mathrm{m}^{3} / \mathrm{T}$ & 93 & 82 & 79 \\
\hline Содержание кислорода в дутье, \% & 24,8 & 25,3 & 26,5 \\
\hline 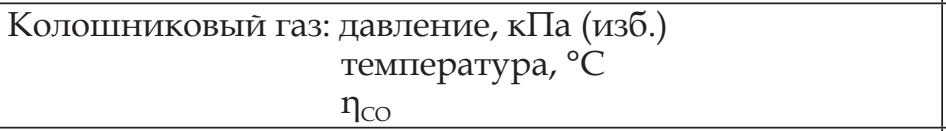 & $\begin{array}{l}189 \\
322 \\
0,41\end{array}$ & $\begin{array}{l}190 \\
333 \\
0,41\end{array}$ & $\begin{array}{l}190 \\
210 \\
0,43\end{array}$ \\
\hline $\begin{array}{r}\text { Анализ чугуна, \%: } \mathrm{Si} \\
\mathrm{Mn} \\
\mathrm{S} \\
\mathrm{P}\end{array}$ & $\begin{array}{l}0,77 \\
0,57 \\
0,038 \\
0,058\end{array}$ & $\begin{array}{l}0,78 \\
0,63 \\
0,040 \\
0,054\end{array}$ & $\begin{array}{c}0,79 \\
0,66 \\
0,042 \\
0,056\end{array}$ \\
\hline Уловленная колошниковая пыль, кг/т & 39 & 35 & 18 \\
\hline Текущие простои, \% & 0,79 & 0,39 & 0,23 \\
\hline тихий ход, \% & 1,42 & 0,23 & 0 \\
\hline Выход шлака, кг/т & 407 & 405 & 380 \\
\hline Содержание Fе во всей шихте, \% & 54,2 & 54,4 & 55,1 \\
\hline Рудная нагрузка на кокс, кг/кг & 3,12 & 3,24 & 3,14 \\
\hline $\begin{aligned} \text { Расходы, кг/т: агломерат ЮГОК } \\
\text { агломерат НКГОК-2 } \\
\text { окатыши СевГОК } \\
\text { известняк }\end{aligned}$ & $\begin{array}{c}1080 \\
0 \\
506 \\
90\end{array}$ & $\begin{array}{c}1155 \\
0 \\
572 \\
80\end{array}$ & $\begin{array}{c}0 \\
1075 \\
655 \\
0\end{array}$ \\
\hline Основность шлака, ед. & 1,25 & 1,25 & 1,25 \\
\hline $\begin{array}{c}\text { Качество кокса, \%: зола } \\
\text { сера } \\
\mathrm{M}_{25} \\
\mathrm{M}_{10} \\
+80 \mathrm{Mм} \\
-25 \mathrm{Mм}\end{array}$ & $\begin{array}{c}10,1 \\
1,63 \\
90,0 \\
4,7 \\
3,8 \\
3,1\end{array}$ & $\begin{array}{c}10,1 \\
1,75 \\
87,6 \\
5,9 \\
4,2 \\
3,3\end{array}$ & $\begin{array}{c}10,1 \\
1,73 \\
88,0 \\
5,9 \\
4,1 \\
2,2\end{array}$ \\
\hline $\begin{array}{r}\text { Фракция 0-5 мм, \%: агломерат ЮГОК } \\
\text { агломерат НКГОК-2 } \\
\text { окатыши СевГОК } \\
\text { Средневзвешенная фракция 0-5 мм, \% }\end{array}$ & $\begin{array}{c}21,8 \\
- \\
5,07 \\
16,44\end{array}$ & $\begin{array}{c}22,07 \\
- \\
5,3 \\
16,52\end{array}$ & $\begin{array}{c}- \\
10,5 \\
6,1 \\
8,8\end{array}$ \\
\hline Кинетическая энергия комбинированного дутья, кДж/с & 53,5 & 51,5 & 64,5 \\
\hline Энергия давления комбинированного дутья, кДж/с & 1897,5 & 1973,1 & 2215,0 \\
\hline $\begin{array}{l}\text { Полная механическая энергия комбинированного } \\
\text { дутья, кДж/с }\end{array}$ & 1951,0 & 2024,6 & 2279,5 \\
\hline Выход горнового газа, $\mathrm{m}^{3} / \mathrm{c}$ & 109,5 & 113,5 & 115,4 \\
\hline Теоретическая температура горения, ${ }^{\circ} \mathrm{C}$ & 1930 & 1968 & 2129 \\
\hline Энергия давления горнового газа, кДж/с & 3891,0 & 4103,6 & 4472,3 \\
\hline Полная механическая энергия горнового газа, кДж/с & 3944,5 & 4155,1 & 4536,8 \\
\hline
\end{tabular}


изменение кинетической энергии в эти периоды. Так, в $\mathrm{O}_{1}$ кинетическая энергия снизилась до 51,5 кДж/с, а в $\mathrm{O}_{2}$ кинетическая энергия выросла до 64,5 кДж/с. Энергия давления комбинированного дутья на срезе фурмы в базовом периоде составляла 1897,5 кДж/с, в О 1 и О 2 энергия давления последовательно росла до 1973,1 и 2215 кДж/с. Соответственно увеличивалась и полная механическая энергия комбинированного дутья - последовательно с 1951,0 до 2024,6 и до 2279,5 кДж/с, что, безусловно, сказалось на увеличении длины зоны горения. А с учетом факта использования фурм диаметром 207 мм увеличилась и ширина зон горения перед этими фурмами.

Полная механическая энергия горнового газа выросла за счет увеличения энергии давления горнового газа в связи с увеличением выхода горнового газа и теоретической температуры горения (табл. 3). Так, энергия давления горнового газа последовательно росла с 3891 кДж/с в базовом периоде до 4103,6 кДж/ с в первом опытном периоде и до 4472,3 кДж/с во втором опытном периоде. Это, соответственно, привело к росту полной механической энергии горнового газа с 3944,5 до 4155,1 и 4536,8 кДж/с в опытных периодах $\mathrm{O}_{1}$ и $\mathrm{O}_{2}$ (табл. 3) и к увеличению глубины проникновения потока газа к центру горна. Изменения на кривых содержания $\mathrm{CO}_{2}$ в газе по радиусу колошника доменной печи (рис. 3) также это подтверждают.

Учитывая, что величина энергии давления в полной механической энергии горнового газа составляет 98,6-98,8 \%, по её величине при отсутствии точных данных о кинетической энергии комбинированного дутья можно судить об изменении полной механической энергии горнового газа и глубине проникновения потока газа к оси горна доменной печи.

Если сравнить значения энергетических параметров на доменной печи № 8 в двух рассматриваемых периодах (табл. 1 и 3), то видно, что полная механическая энергия комбинированного дутья, отвечающая за длину зоны горения, при чередовании фурм диаметром 190/207 мм была больше на 8,8 \%, а полная механическая энергия горнового газа, отвечающая за глубину проникновения потока газа к оси горна печи, также была больше на 17,6 \%. Это улучшило равномерность распределения газового потока по сечению доменной печи и позволило увеличить активную площадь зон горения в наиболее нагруженной железорудными материалами периферийной зоне печи. Последнее обстоятельство дополнительно расширило возможности увеличения удельной производительности доменной печи при улучшении показателей качества шихтовых материалов.
В последующие периоды доменная печь № 8 работала уже на фурмах диаметром 165 мм, а с 1980 г. и основность агломерата НКГОК-2 стала снижаться до уровня 1,4 и далее до 1,2-1,25 д. ед. из-за того, что предприятие перестало использовать в шихте доменных печей окатыши. Это, безусловно, сказалось на прочностных характеристиках агломерата. Как известно, при такой основности агломерат имеет самую низкую прочность. В настоящее время основность агломерата АЦ-2 АДД АМКР снижена до 1,06-1,12 д. ед. (из-за снижения содержания серы в коксе, поставляемом в доменные цехи АМКР), а ПАО ЮГОК стал производить агломерат основностью 1,6 д. ед. при содержании фракции 0-5 мм 9,16 \% и периодически - агломерат основностью 0,5 д. ед. при содержании фракции 0-5 мм 9,74 \% .

Выводы и перспективы развития направления. Опыт работы доменных печей объемом 2700 и 2000 м 3 на грохоченном, освобожденном от мелочи охлажденном агломерате и при использовании кокса с высоким показателем послереакционной прочности CSR подтвердил известный факт зависимости производительности печей и расхода кокса не только от качества шихтовых материалов, но и от распределения газового потока по сечению печи. В частности чередование фурм разного диаметра дополнительно способствует усилению положительного эффекта за счет расширения зон горения в горне печи. А если при этом растет полная механическая энергия горнового газа и увеличивается глубина проникновения горнового газа к оси печи, эффект от использования высококачественного сырья может быть максимальным.

\section{Библиографический список/References}

1. Донсков Е. Г. Опыт загрузки доменных печей засыпным аппаратом с лепестковым распределителем шихты / Е. Г. Донсков, В. П. Лялюк, В. И. Ильченко и др. / / Сталь. - 2009. - № 6. C. 11-16.

Donskov E. G., Lyalyuk V. P., Il'chenko V. I. Opyt zagruzki domennyh pechej zasypnym apparatom s lepestkovym raspredelitelem shihty. Stal. 2009, no. 6, pp. 11-16.

2. Листопадов В. С. Результаты работы доменной печи № 7 «АрселорМиттал Кривой Рог» с калибратором Тарасова / В. С. Листопадов, О. Н. Мирошниченко, А. В. Романчук и др. // Сталь. - 2015. - № 2. - С. 10-12.

Listopadov V. S., Miroshnichenko O. N., Romanchuk A. V. Rezultatyi rabotyi domennoy pechi no. 7 "ArselorMittal Krivoy Rog" s kalibratorom Tarasova. Stal. 2015, no. 2, pp. 10-12.

3. Лялюк В. П. Выбор режимов доменной плавки на комбинированном дутье с оценкой 
параметров фурменной зоны / В. П. Лялюк, И. Г. Товаровский / / Черные металлы. - 2003. № 11. - С. 13-16.

Lyalyuk V. P., Tovarovskij I. G. Vybor rezhimov domennoj plavki na kombinirovannom dut'e socenkoj parametrov furmennoj zony. Chernye metally. 2003, no. 11, pp. 13-16.

4. Лялюк В. П. Методика расчета полной энергии горнового газа при вдувании пылеугольного топлива / В. П. Лялюк, А. К. Тараканов, Д. А. Кассим / / Сталь. - 2017. - № 3. - С. 2-8.

Lyalyuk V. P., Tarakanov A. K., Kassim D. A. Metodika rascheta polnoj ehnergii gornovogo gaza pri vduvanii pyleugol'nogo topliva. Stal. 2017, no. 3, pp. 2-8.

5. Прокофьев И. А. Работа доменной печи с использованием освобожденного от мелочи высокоосновного агломерата / И. А. Прокофьев, И. Г. Товаровский, В. И. Бондаренко и др. // Сталь. - 1979. - № 5. - С. 332-333.

Prokof'ev I. A., Tovarovskij I. G., Bondarenko V. I. Rabota domennoj pechi s ispol'zovaniem osvobozhdennogo ot melochi vysokoosnovnogo aglomerata. Stal. 1979, no. 5, pp. 332-333.

6. Донсков Е. Г. Работа доменной печи на фурмах различного диаметра с использованием освобожденного от мелочи высокоосновного агломерата / Е. Г. Донсков, В. П. Лялюк, Р. Д. Каменев и др. / / Металлургическая и горнорудная промышленность. - 1982. - № 3. - С. 7-9.

Donskov E. G., Lyalyuk V. P., Kamenev R. D. Rabota domennoj pechi na furmah razlichnogo diametra s ispol'zovaniem osvobozhdennogo ot melochi vysokoosnovnogo aglomerata. Metallurgicheskaya i gornorudnaya promyshlennost. 1982, no. 3, pp. 7-9.

7. Лялюк В. П. Опыт использования высококачественного окускованного железорудного сырья в доменной плавке / В. П. Лялюк, В. А. Шеремет, А. В. Кекух и др. // Металлургическая и горнорудная промышленность. - 2010. - № 6. - С. 6-9.

Lyalyuk V. P., Sheremet V. A., Kekuh A. V. Opyt ispol'zovaniya vysokoka-chestvennogo okuskovannogo zhelezorudnogo syr'ya v domennoj plavke. Metallurgicheskaya i gornorudnaya promyshlennost. 2010, no. 6, pp. 6-9.

Мета. Порівняти результати ефрективності доменної плавки при зміні якісних характеристик агломерату і коксу, а також розрахункових показників дуттьового режиму плавки.

Методика. Аналіз техніко-економічних показників роботи доменних печей у періоди роботи на агломераті з різними металургійними характеристиками і різним діаметром фурм.

Результати. Досвід роботи доменних печей об'ємом 2700 і 2000 м $^{3}$ підтвердив відомий фракт залежності продуктивності печей і витрати коксу не тільки від якості шихтових матеріалів, а й від розподілу газового потоку по перетину печі.
Наукова новизна. Виконано технологічний аналіз результатів роботи доменних печей об'ємом 2700 i 2000 м $^{3}$ при зміні якості агломерату та обкотишів у поєднанні зі зміною параметрів дуттьового режиму плавки. На підставі виконаного аналізу підтверджено доцільність при підвищенні газопроникності шихти за рахунок поліпшення якості сировини одночасного збільшення повних механічних енергій комбінованого дуття і горнового газу, що відповідають за довжину зони горіння і глибину проникнення газового потоку до центру горна доменної печі.

Практична значущість. Чергування фрурм різного діаметру, разом з поліпшенням якісних характеристик шихтових матеріалів, додатково сприяє посиленню позитивного ефректу за рахунок розширення зон горіння в горні печі. Якщо при цьому зростає повна механічна енергія горнового газу і збільшується глибина проникнення горнового газу до осі печі, ефрект від використання високоякісної сировини може бути максимальним.

Ключові слова: агломерат, кокс, дуття, фурми, газопроникність, якість, повна енергія.

Purpose. Compare the results of blast furnace smelting efficiency, when changing the qualitative characteristics of the sinter and coke, and the calculated parameters of the blowing regime of melting.

Methodology. Analysis of technical and economic performance of blast furnaces during periods of work on the agglomerate with different metallurgical characteristics and different diameter of the tuyeres.

Findings. The experience of blast furnaces with a volume of 2700 and $2000 \mathrm{~m}^{3}$ confirmed a known fact of the dependence of furnace efficiency and coke consumption not only through the quality of charge materials, but also through the distribution of the gas flow along the furnace section.

Originality. The technological analysis of the results of the operation of blast furnaces with the volume of 2700 and $2000 \mathrm{~m}^{3}$ with a change of the quality of the sinter and pellets in combination with the change of the blowing regime parameters was performed. On the basis of the performed analysis, it was confirmed the expediency of increasing the gas permeability of the charge by improving the quality of the raw materials while increasing the total mechanical energy of the combined gas-blast and hearthgas, which are responsible for the length of the combustion zone and the depth of penetration of the gas flow to the center of the blast furnace.

Practical value. Alternation of tuyeres of different diameters along with the improvement of the quality characteristics of charge materials, additionally contributes to the enhancement of the positive effect due to the expansion of the combustion zones in the furnace hearth. And if in this case the total mechanical energy of the mountain gas rises and the depth of penetration of the furnace gas to the furnace axis increases, the effect of using high-quality raw materials can be maximized.

Key words. agglomerate, coke, blowing, tuyeres, gas permeability, quality, total energy.

Рекомендована к публикации д. т. н. И. Г. Муравьевой Потупила 10.09.2018 